\title{
Захарова В.В.
}

\section{Процесс структуризации сети научных организаций, подведомственных Федеральному агентству научных организаций, в 2016 году: обзор прессы}

\author{
Zakharova V.V. \\ The process of structuring of a network of scientific \\ organizations under The Federal agency for scientific \\ organizations in 2016: the press review
}

В данной статье авторами выполнен краткий обзор официальных сайтов Федерального агентства научных организаций, Российской академии наук с целью освещения хода процесса реструктуризации сети научных организаций в течение января-октября 2016 года

Ключевые слова: научные организации, РАН, ФАНО России, структуризация

\section{Захарова Виктория Владимировна \\ Младший научный сотрудник \\ Институт философии и права Уральского отделения Российской академии наук \\ г. Екатеринбург, ул. С. Ковалевской, 16}

The paper briefly examines the overview of the official websites of the Federal Agency for Scientific Organizations and the Russian Academy of Sciences to highlight the course of the restructuring process the network of scientific organizations in JanuaryOctober 2016

Key words: scientific organizations, RAS, FASO Russia, structuring
Zakharova Victoriia Vladimirovna Junior Researcher Institute of philosophy and law of the Ural branch of the Russian Academy of Sciences Ekaterinburg, S. Kovalevskaya st., 16

С момента старта реформы Российской академии наук (РАН), Российской академии сельскохозяйственных наук (РАСХН) и Российской академии медицинских наук (РАMН) прошло более трех лет. В соответствии с положениями давшего старт реформе Федерального закона от 27.09.2013 № 253-ФЗ научные организации, ранее подведомственные РАН, РАМН и РАСХН, переданы в подведомственность вновь созданного Федерального агентства научных организаций (ФАНО России, Агентство).

Согласно публичной декларации целей и задач ФАНО России в 2016 году, одной из приоритетных целей Агентства является структурная модернизация сектора исследований и разработок, в том числе путем проведения структуризации научных организаций. Необходимость проведения реструктуризации научных организаций определена поручением Президента Российской Федерации от 27.12.2014 по итогам заседания Совета по науке и образованию при Президенте Российской Федерации от 08.12.2014. Также Президентом Российской 
Федерации по итогам заседания Совета по науке и образованию при Президенте Российской Федерации от 21.01.2016 было дано поручение принять меры по ускорению реструктуризации сети научных организаций, подведомственных ФАНО России. Для реализации указанных поручений в полномочия Агентства входит предоставление в Правительство РФ согласованных с федеральным государственным бюджетным учреждением «Российская академия наук» предложений о создании, реорганизации и ликвидации организаций, подведомственных Агентству [1, 2].

В 2014 году были выбраны пилотные проекты создания Федеральных исследовательских центров (ФИЦ), направленные на решение приоритетных научных задач:

- ФИЦ «Информатика и управление» РАН;

- ФИЦ «Институт цитологии и генетики СО РАН»;

- ФИЦ «Фундаментальные основы биотехнологии» РАН;

- ФИЦ Всероссийский институт генетических ресурсов растений имени Н.И. Вавилова;

- ФИЦ «Научно-исследовательский институт системных исследований $\mathrm{PAH}$ ».

В мае 2016 года создание 5 федеральных исследовательских центров состоялось, организации завершили процедуры юридического оформления и приступили к работе в новом составе. Первые итоги работы были подведены на заседании Научно-координационного совета при ФАНО России, где было принято решение продолжить мониторинг эффективности работы первых созданных ФИЦ в связи с тем, что короткие сроки работы центров не позволяют в полной мере судить об их эффективности [2].

Согласно отчету Агентства о реализации Публичной декларации целей и задач за I полугодие 2016 года число организаций, инициировавших проекты реструктуризации, выросло с 17\% (123 организации, 25 проектов) до 29\% (269 организаций, 63 проекта) в период с июня 2015 года по июль 2016 года. Из 63 проектов 20 проектов завершены (реорганизовано 82 организации), по 11 проектам приняты решения (49 организаций), 12 проектов находятся на рассмотрении (51 организация) и 20 проектов инициировано (87 организаций).

В феврале 2016 года на официальном портале Красноярского края появилась информация о создании Красноярского ФИЦ, который будет открыт на базе Красноярского научного центра Сибирского отделения Российской академии наук и объединит 11 научных институтов, работающих в регионе. Приоритетные задачи центра - фундаментальные и прикладные исследования в области космоса, информационных и биосферных технологий.

На протяжении января-ноября 2016 года бюро Научно-координационного совета при ФАНО России продолжило работу по рассмотрению концепций развития создаваемых Федеральных исследовательских центров. Так, на заседании в апреле 2016 года была одобрена концепция программ развития сразу двух исследовательских центров: Уфимского федерального исследовательского центра Российской академии наук (УФИЦ РАН, объединит 11 организаций) и Перм- 
ского федерального исследовательского центра Уральского отделения Российской академии наук (ПФИЦ УрО РАН, объединит 6 организаций). Деятельность мультидисциплинарного УФИЦ РАН будет направлена на проведение фундаментальных исследований мирового уровня и достижение прорывных результатов (особое внимание в создаваемом центре будет уделяться исследованиям, связанным с химическими и информационными технологиями), а также координацию и проведение междисциплинарных исследований, ориентированных на решение важнейших проблем социально-экономического и культурного развития Российской Федерации и Республики Башкортостан. В свою очередь деятельность ПФИЦ УрО РАН будет направлена на изучение вопросов безопасности природных и техногенных систем.

В июле 2016 года на заседании Бюро Научно-координационного совета при ФАНО России были одобрены проекты Концепций программы развития Федерального государственного бюджетного учреждения науки Федерального исследовательского центра «Коми научный центр уральского отделения Российской академии наук» (ФГБУН ФИЦ «Коми НЦ УрО РАН», объединит 9 организаций) и Федерального государственного бюджетного учреждения науки Федерального исследовательского центра «Якутский научный центр СО РАН» (ФИЦ ЯНЦ CO РАН, 9 организаций). ФИЦ в Республике Коми создаётся в целях проведения комплексных междисциплинарных и мультидисциплинарных исследований по приоритетным направлениям науки и внедрения их в практику для обеспечения устойчивого развития Севера и Арктики России. Одна из задач будущей структуры в Республике Саха - усилить междисциплинарное и межотраслевое научное сотрудничество академических институтов по ключевым направлениям развития. Среди приоритетов - получение новых знаний и технологий для горной промышленности и геологического кластера, медицины, фармакологии. Особое внимание центр будет уделять развитию общественно-гуманитарных наук.

В сентябре 2016 года бюро Научно-координационного совета при ФАНО России одобрило концепцию развития Федерального исследовательского центра «Пущинский научный центр биологических исследований РАН» (8 организаций). Ключевым принципом реализации программы является организация современного исследовательского центра мирового уровня на основе взаимодополнения направлений современной биологической науки.

Необходимо отметить, что далеко не всегда Российская академия наук, ее региональные отделения, а также ученые советы и научные коллективы поддерживают участие организаций в проектах рестурктуризации. В марте 2016 года президиум Сибирского отделения Российской академии наук решительно высказался против объединения научно-исследовательских институтов только лишь по географическому признаку, без учёта их специфики [3]. Неоднозначные оценки в прессе давались объединениям, проходящим в Кабардино-Балкарии и Якутии. Против объединения выступил ряд коллективов научных учреждений Екатеринбурга. 


\section{Список используемых источников:}

1. Федеральный закон РФ от 27 сентября 201№ 253-ФЗ «О Российской академии наук, реорганизации государственных академий наук и внесении изменений в отдельные законодательные акты Российской Федерации»;

2. Официальный сайт Федерального агентства научных организаций. http://fano.gov.ru.

Свидетельство о регистрации СМИ Эл № ФС77-66823 от 15 августа 2016 года.

3. Официальный сайт Российской академии наук. http://ras.ru.

(C) 2016, Захарова В.B.

Процесс структуризации сети научных организаций, подведомственных Федеральному агентству научных организаций, в 2016 году: обзор прессы

\section{(C) 2016, Zakharova V.V.}

The process of structuring of a network of scientific organizations under The Federal agency for scientific organizations in 2016: the press review 